Article

\title{
Paving the Way for Self-Employment: Does Society Matter?
}

\author{
Zulaicha Parastuty ${ }^{1, *(1)}$ and Dieter Bögenhold ${ }^{2}$ (i) \\ 1 Department of Innovation Management and Entrepreneurship, Alpen-Adria Universität Klagenfurt, \\ Klagenfurt 9020, Austria \\ 2 Department of Sociology, Alpen-Adria Universität Klagenfurt, Klagenfurt 9020, Austria; \\ Dieter.Boegenhold@aau.at \\ * Correspondence: Zulaicha.Parastuty@aau.at; Tel.: +43-463-2700-4059
}

Received: 27 November 2018; Accepted: 30 January 2019; Published: 31 January 2019

\begin{abstract}
This paper empirically investigates the extent to which institutional and individual factors predict the level of intention relating to self-employment. Arriving at a better understanding of intentions will assist to provide answers as to why ratios of self-employment are as they are and how public and economic policy may respond to an often perceived requirement to increase the level of self-employment. Using the dataset of 2017 Amway Global Entrepreneurship Research (AGER) for Austria, the United Kingdom, Italy, the United States, and Brazil this study finds that all variables predicting the intention to enter self-employment are significant at varying degree. The research explores the interplay between age, risk, gender, and education, on the one hand, and unemployment (OECD Labour Force Statistics) and political constitution as measured by the EFW index, on the other hand. Distinguishing between "no intention", an "indifferent intention," and a "strong intention" towards self-employment, the findings show that all variables can predict a willingness for self-employment in different, but significant, ways to comparable measures (an indifferent intention relative to no intention, and a strong intention to no intention). The paper concludes with an outlook to some more general perspectives of institutional economics and needs for further research.
\end{abstract}

Keywords: entrepreneurial intention; unemployment; self-employment; entrepreneurship

\section{Introduction}

Entrepreneurship is considered to be an engine for economic growth, labour market stabilization and business competitiveness. Countries with higher and/or increasing entrepreneurial initiative indexes tend to have lower levels of unemployment [1]. In addition to its economic importance, self-employment is often regarded as a key to a better life and social status. Yet, "the entrepreneurial resource is scarce" [2]. Therefore, the consensus is to promote entrepreneurship [3], for example by increasing people's intention to enter self-employment.

This study focuses on the issue of intentions to become self-employed. These intentions must be understood as dispositions which are measured by several factors, including motivational factors affecting the desirability of starting a business, feasibility, as in feeling prepared to start a business, and stability against social pressure, in the sense that social ties do not dissuade people from starting a business $[4,5]$.

Arriving at a better understanding of intentions will help provide answers as to why ratios of self-employment are as they are and how public and economic policy may respond to an often perceived requirement to increase the level of self-employment entries. There has been growing and evolving attention to entrepreneurial intention, yet a call to better understand entrepreneurial intention remains [6]. 
Higher or lower ratios of intentions to enter self-employment are not necessarily "better" or "worse" because "overoptimism might be associated with a higher probability of both exploitation and failure" ([7], p.224), while those who are more "pessimistic" may evaluate risks more appropriately and have a better idea of the fact that many others have the same ideas at the same time. In general, it is very difficult to distinguish between optimism and overconfidence. At the very least it is related to intended market entry but not to the market position (entrepreneurial orientation) of the business [8]. Measuring intentions between pessimism, optimism, and overconfidence ultimately refers to further discussion in psychology $[9,10]$ and behavioural economics [11].

This study attempts to compare the selected European and non-European countries. International comparisons are particularly able to highlight convergences and divergences when investigating general patterns of economic and social development. Embodying norms about what is legitimate, appropriate and desirable in a particular national context, societal culture is widely recognised as affecting the economic behaviour of individuals in general and their occupational choices in particular [12,13].

The study explores the congruencies and incongruencies of intentions for self-employment in the countries concerned. The paper attempts to discuss findings in relation to institutional determinants as included in the OECD's Labour Force Statistics or the index of Economic Freedom of the World (EFW) in order to link the empirical observations to theoretical concepts of institutions and human capital. We rely on interaction between the individual and institutional processes to predict intentions to enter self-employment.

\section{Intention to Become Self-Employed}

Intention is acknowledged to be one of the central features of human beings [14]. Intention constructs a depiction of the direction of future action. It affects individuals' choices, as well as guiding and preserving behaviour. With regards to intention to self-employment, the future action is developing an entrepreneurial venture [15].

To understand intention to self-employment, there are three primary models: 1) the model for implementing entrepreneurial ideas developed by Bird [16], 2) the model for an entrepreneurial event by Shapero and Sokol [17], and 3) the model for planned behaviour introduced by Ajzen [18]. While only a few studies have validated Bird's model, Shapero-Sokol and Ajzen's models are both widely applied empirically [6]. Having tested both models, Krueger et al. support their applicability in explaining intention by individual and situational variables [15]. However, the theory of planned behaviour (TPB) by Azjen (1991) has been most consistently shown to predict entrepreneurial intention [19-21].

Azjen (1991) argues that intention generally depends on perceptions of individual attractiveness, feasibility (perceived behaviour control) and social norms. Attractiveness means an individual has favourable or unfavourable assessments of being an entrepreneur. The assessment does not only include affective but also evaluative considerations [22]. The feasibility construct refers to the perception of the easiness or difficulty of being an entrepreneur. This differs from the concepts of self-efficacy [23] and feasibility [17] because TPB does not only include the perception of ability but also perceptions of the controllability of being an entrepreneur [24]. Finally, social norms relate to social pressure to become an entrepreneur, which consists of normative beliefs and motivation to comply with those beliefs. Normative beliefs concern perceptions of rejection or approval by close social ties about being an entrepreneur. Close social ties set the norm that specifies how the individual should behave. Motivation to comply then refers to an individual's willingness to conform to these norms that is to act according to the expectations of significant others. Social norms can become a trigger or a barrier to becoming an entrepreneur.

Ajzen [24] points out that the three antecedents of intentions are determined by specific behaviour and situations. As Welter [25] suggests, "there is growing recognition in entrepreneurship research that economic behaviour can be better understood within its historical, temporal, institutional, spatial 
and social context". Thus, a strong need to examine the heterogeneous aspect of context still exists [26]. Spatial and institutional contexts may have been widely used to explain intention; however, many factors need to be examined to understand how the contexts interact with individuals in determining their entrepreneurial intentions.

\subsection{Spatial Context and Institutional Factors}

Spatial context, i.e., country, has been used as a construct to understand the formation of intention in several studies [6]. Cross-country analyses involving more than two-country samples mostly utilize samples of students, e.g., [20,27] and/or GEM data, e.g., [28,29]. Such studies have shown the breadth applicability of intention models. For example, studies using GEM data confirm the applicability of the intention model with some variations on the influence of motivational antecedents.

North [30] defines institutions as "the humanly devised constraints that structure political, economic and social interaction" (p.97). The constraints consist of both informal dimensions (traditions, code of conduct) and formal ones (laws, constitutions, property rights) [31,32]. Institutions differ across nations, societies and cultures, with divergent results in the patterns of economic behaviour [33]. A study by Liñán, et al. [34] suggests that the more favourable institutions are, the higher the entrepreneurial intention. Formal institutions, i.e.., regulative systems and legal policies, are obviously significant [35], yet informal institutions are equally influential [36]. In this regard, the culture of society plays a role affecting the levels of entrepreneurial intention [37]. Previous research has indicated the key moderating role of social values on the relationship between institutions and entrepreneurship [38]. Culture, in various forms, is depicted as a moderator of the relationship between contextual factors and entrepreneurial outcomes. The moderating role of culture highlights the fact that national culture acts as a catalyst rather than as a causal agent of entrepreneurial outcomes [39]. Most recently, Block et al. concluded that it seems "likely that societal-level factors, such as culture, may differentially affect individual inclinations to become self-employed on a full- or a part-time basis" [13].

In the context of formal institutions, economic freedom, defined as a market economy-oriented institution, and policy may be of importance for entrepreneurial activity. Economic dimensions, compromising legal structures, government, property rights, labour, financial structures and business environments, may affect intentions to enter self-employment. Several studies have revealed an association between economic freedom and entrepreneurial activity [40,41]. It can be argued that greater economic freedom offers greater opportunities and higher rewards for creating a new venture. Market economy-oriented institutions and policies providing regulatory and legal frameworks may assist the exploitation of entrepreneurial opportunities [42].

The general labour market situation is of crucial importance among different institutional factors influencing intentions and concrete entries to self-employment. Blanchflower [43] observed a large set of OECD countries for the time from 1966 to 1996, suggesting that self-employment is predominantly male and more prevalent among older age groups than it is among the young. Constant and Zimmermann [44] analyzed labour market transitions among self-employment, gainful employment, and unemployment across the business cycle comparing the performance of migrants and natives in Germany. They could show the same cycles to self-employment but in different extends. The entry transition to self-employment of Germans was three times higher. Evans and Leighton [45] found that white men who are unemployed are nearly twice as likely as wage or salary dependent workers to enter self-employment. Thurik et al. [46] argued in a more differentiated fashion that there is both a "recession-push" and a "prosperity-pull" aspect of the relation between unemployment and self-employment. In their analysis of a broad sample of countries worldwide, Falco and Haywood [47] reported the varying attractiveness of self-employment for different degrees of education and professional backgrounds while Dvouletý [48] showed a weak, but positive, relationship between self-employment and unemployment for the Czech Republic. The same could be shown earlier in a study by Moore and Mueller [49] for the case of Canada. 


\subsection{Personal Factors}

Personal factors have been widely investigated as significant variables influencing intentions to self-employment [6]. With regard to gender, it is generally believed that males have a stronger entrepreneurial intention than females [50]. Males also show a more positive attitude towards entrepreneurship [51]. Additionally, males exhibit a more positive perceived feasibility. Females, in contrast, perceive different barriers to entrepreneurship [50]. Although the gap is not consistent across cultures, the perception of barriers to entrepreneurship may explain why females transform their intentions into action to a lesser extent than males [52]. Furthermore, a study in China, the US and Belgium has showed that gender seems to matter in how individuals perceive a lack of support which is significantly more important for females than males [50]. Nevertheless, results relating to gender and culture need further explanation.

Female-owned businesses are one of the fastest-growing entrepreneurial populations in a world of growth rates [53]. These developments raise the question as to whether self-employment can be seen as a strategy for women to participate in the labour market and to achieve a good work-life balance [54,55]. One of the most consistent findings in studies on women's labour force participation is the negative effect of the presence of young children on the probability of participation. It could be argued that difficulties in combining work and family enhance the transition or entry into self-employment [56]. Gender-based discussions are very rich in divergent sets of academic argumentation with respect to evaluating patterns of social mobility and corresponding decisions to keep or change jobs $[57,58]$. Self-employment may reflect the development of more or less successful strategies for coping with the conflicts arising from the difficult balance of employment and family life [59] and always dealing with a mix between pushing and pulling factors so that the many female owned micro enterprises are very heterogeneous [60].

At a macro-structural level, it can be observed that an increase in female self-employment goes hand in hand with a shift towards a service sector economy and an increase in solo self-employment [61,62]. Lastly, gender presentations in self-employment correspond partly to different degrees of intention to participate and to move towards self-employment [63].

Regarding age, although an increase in self-employed people at an advanced age can be observed in empirical analyses, there is no consensus about the reasons behind this development $[64,65]$. Numerous findings are partly divergent and contradictory, given that past studies on intention mostly relied on samples of students (see Table 1). However, what definitely is known is that one's life-course is limited and personal labour biographies change according to one's position in that biography [66]. Planning horizons of decisions to enter self-employment vary according to age.

Empirical evidence also shows that human capital, or more specifically the level of education, is a noticeable factor for success in entrepreneurship [67-69]. With regards to entrepreneurial intention, it is generally assumed that there is a positive relationship between education and intention to enter self-employment. However, a meta-analysis carried out by van der Sluis et al. [70] shows that there is no relationship between general education and venture foundation. While Dickson et al. [71] also confirm the missing link, their study found a positive link between entrepreneurship education and the decision to become an entrepreneur. Further, a meta-analysis of 73 studies revealed that entrepreneurship education is a more effective pedagogical approach to increasing a student's entrepreneurial intentions than business education [72]. 
Table 1. Summary studies on entrepreneurial intention.

\begin{tabular}{|c|c|c|c|c|c|c|}
\hline Authors (Year) & Title & Journal & Sample & Independent Variables & Control Variables & Results \\
\hline $\begin{array}{l}\text { Liñán, Urbano, } \\
\text { and Guerrero } \\
\quad(2011)\end{array}$ & $\begin{array}{l}\text { Regional variations in } \\
\text { entrepreneurial } \\
\text { cognitions: Start-up } \\
\text { intentions of university } \\
\text { students in Spain }\end{array}$ & $\begin{array}{l}\text { Entrepreneurship } \\
\text { and Regional } \\
\text { Development }\end{array}$ & $\begin{array}{l}549 \text { University students } \\
\text { (Spain) }\end{array}$ & $\begin{array}{l}\text { Motivational factors (attitude towards } \\
\text { the behaviour, PBC (perceived } \\
\text { easiness to start a business), subjective } \\
\text { norms environmental factors (closer } \\
\text { valuation, social valuation) }\end{array}$ & $\begin{array}{l}\text { Situational factors (role } \\
\text { model, gender, age, } \\
\text { immigrant, labour } \\
\text { experience, self-employment } \\
\text { experience) }\end{array}$ & $\begin{array}{l}\text { There are regional differences in EI. } \\
\text { Social valuation is higher in more } \\
\text { developed region, positively } \\
\text { affecting perceived subjective } \\
\text { norms and behavioural control. }\end{array}$ \\
\hline $\begin{array}{l}\text { Walker, Jeger, } \\
\text { and Kopecki } \\
\quad(2013)\end{array}$ & $\begin{array}{l}\text { The Role of Perceived } \\
\text { Abilities, Subjective } \\
\text { Norm and Intentions in } \\
\text { Entrepreneurial } \\
\text { Activity. }\end{array}$ & $\begin{array}{l}\text { The Journal of } \\
\text { Entrepreneurship }\end{array}$ & $\begin{array}{l}\text { 86,000 respondents } \\
\text { from GEM data } \\
\text { 2003-2011 (43 } \\
\text { countries) }\end{array}$ & Ability, subjective norms & $\begin{array}{l}\text { Skills, perceived good, } \\
\text { perceived high status, stories } \\
\text { in media, GDP, fear of failure, } \\
\text { perceived similar standard } \\
\text { of living }\end{array}$ & $\begin{array}{l}\text { Intention is positively correlated } \\
\text { with perceived good, stories in } \\
\text { media, skills. GDP is negatively } \\
\text { correlated with intention. }\end{array}$ \\
\hline $\begin{array}{l}\text { Van Gelderen et } \\
\text { al. (2008) }\end{array}$ & $\begin{array}{c}\text { Explaining } \\
\text { entrepreneurial } \\
\text { intentions by means of } \\
\text { the theory of planned } \\
\text { behaviour. }\end{array}$ & $\begin{array}{l}\text { Career } \\
\text { Development } \\
\text { International }\end{array}$ & $\begin{array}{l}1235 \text { Undergraduate } \\
\text { students (The } \\
\text { Netherlands) }\end{array}$ & $\begin{array}{c}\text { Attitude (importance of autonomy, } \\
\text { importance of wealth, challenge, } \\
\text { financial security, work load } \\
\text { avoidance), Behavioural control } \\
\text { (Perseverance, creativity, } \\
\text { entrepreneurial alertness, self-efficacy), } \\
\text { Subjective norms }\end{array}$ & & $\begin{array}{l}\text { Entrepreneurial alertness is } \\
\text { positively correlated with EI. } \\
\text { Perceived control and self-efficacy } \\
\text { are not consistent predicting EI. } \\
\text { Financial security is negatively } \\
\text { correlated with EI. }\end{array}$ \\
\hline $\begin{array}{l}\text { Engle, Schlaegel, } \\
\text { and Dimitriadi } \\
\text { (2011) }\end{array}$ & $\begin{array}{l}\text { Institutions and } \\
\text { Entrepreneurial Intent: } \\
\text { A cross-country study }\end{array}$ & $\begin{array}{l}\text { Journal of } \\
\text { Developmental } \\
\text { Entrepreneurship }\end{array}$ & $\begin{array}{l}477 \text { University students } \\
\text { (Germany, Russia, US) }\end{array}$ & $\begin{array}{l}\text { Informal institutional factors (need, } \\
\text { parental experience, social norms), } \\
\text { Formal institutional factors (economic } \\
\text { situation, close, contracts, corruption, } \\
\text { employment, infrastructure, starting } \\
\text { business, tax, trade) }\end{array}$ & Age, gender & $\begin{array}{l}\text { The results only give minor } \\
\text { support for the influence of formal } \\
\text { institutional factors on EI. Greater } \\
\text { impact appears to come from } \\
\text { informal institutions of need, social } \\
\text { norms and parental experience. }\end{array}$ \\
\hline $\begin{array}{l}\text { Moriano et al. } \\
\text { (2012) }\end{array}$ & $\begin{array}{l}\text { A Cross-Cultural } \\
\text { Approach to } \\
\text { Understanding } \\
\text { Entrepreneurial } \\
\text { Intention }\end{array}$ & $\begin{array}{l}\text { Journal of } \\
\text { Career } \\
\text { Development }\end{array}$ & $\begin{array}{l}1074 \text { University } \\
\text { students (Germany, } \\
\text { India, Iran, Poland, } \\
\text { Spain and the } \\
\text { Netherlands) }\end{array}$ & $\begin{array}{l}\text { Attitude, entrepreneurial self-efficacy, } \\
\text { subjective norms }\end{array}$ & & $\begin{array}{l}\text { Attitude toward entrepreneurship } \\
\text { and entrepreneurial self-efficacy } \\
\text { are equally strong and comparable } \\
\text { across countries influencing EI. } \\
\text { Subjective norms appears to be the } \\
\text { least predictor. }\end{array}$ \\
\hline $\begin{array}{l}\text { Engle et al. } \\
\text { (2010) }\end{array}$ & $\begin{array}{l}\text { Entrepreneurial intent: } \\
\text { A twelve-country } \\
\text { evaluation of Ajzen's } \\
\text { model of planned } \\
\text { behaviour }\end{array}$ & $\begin{array}{l}\text { International } \\
\text { Journal of } \\
\text { Entrepreneurial } \\
\text { Behaviour and } \\
\text { Research }\end{array}$ & $\begin{array}{l}1748 \text { University } \\
\text { students (12 countries) }\end{array}$ & $\begin{array}{l}\text { Entrepreneurial self-efficacy, } \\
\text { achievement motivation, personal } \\
\text { wealth, autonomy, social norms }\end{array}$ & & $\begin{array}{l}\text { Significant contributing model } \\
\text { elements differ by country as well } \\
\text { as the variance explained. Social } \\
\text { norms is a significant predictor in } \\
\text { each country. }\end{array}$ \\
\hline $\begin{array}{l}\text { Iakovleva, } \\
\text { Kolvereid, and } \\
\text { Stephan (2011) }\end{array}$ & $\begin{array}{c}\text { Entrepreneurial } \\
\text { intentions in } \\
\text { developing and } \\
\text { developed countries }\end{array}$ & $\begin{array}{l}\text { Education }+ \\
\text { Training }\end{array}$ & $\begin{array}{c}2225 \text { University } \\
\text { students ( } 5 \text { developing } \\
\text { countries, } 8 \text { developed } \\
\text { countries) }\end{array}$ & $\begin{array}{l}\text { Attitude, perceived behavioural } \\
\text { control, subjective norms }\end{array}$ & $\begin{array}{l}\text { Age, gender, past } \\
\text { self-employment }\end{array}$ & $\begin{array}{l}\text { Stronger EI is found stronger in } \\
\text { developing countries than } \\
\text { developed countries. }\end{array}$ \\
\hline
\end{tabular}


Further discussions turn to the attitude toward risk, which is often argued to be involved in the decision to enter self-employment [73]. The prominent economic approach views is that an individual's decision to enter wage- or self-employment is determined by the relative returns offered in these sectors. Returns confer utility, and individuals choose the option which maximizes expected utility [74,75]. This approach captures forces such as 'unemployment push and pull' factors (whereby unemployed persons are either pushed into self-employment or are pulled in by incentives on the supply side) since in both cases, individuals are making a choice based on relative returns. In addition to the risks, high uncertainty is also associated with entering self-employment [76]. Dew et al. [77] argue that people who think about uncertainty and risk in terms of an affordable loss (i.e., pursing opportunities without investing more resources than they can afford to lose, thereby limiting potential problems) and those who have a larger affordable loss are more likely to decide to enter self-employment.

This article sums up the literature review section by providing Table 1 showing several studies on entrepreneurial intention.

\section{Data and Variables}

\subsection{Hypothesis}

The basic premise of this study is built around the discourses of institutions through the mechanism of individual factors which drive intentions to enter self-employment. The aim is to predict the intention to enter self-employment as a function of institutional factors shaped by individual characteristics. The hypotheses are formulated as follows:

Hypothesis 1. (H1). Increasing unemployment is positively associated with intentions to enter self-employment.

Hypothesis 2. (H2). Greater economic freedom is positively associated with intentions to enter self-employment.

\subsection{Sample}

In order to predict intentions to self-employment, two levels of datasets are used. The first dataset is the individual level dataset of the AMWAY Global Entrepreneurship Report (AGER), which contains detailed occupational data on employment intentions at an individual level. The AGER has been conducted since 2013 in 44 countries by the market research institution GfK (Gesellschaft für Konsumforschung) Germany and the TU Munich [78]. The second dataset contains national level data. National data were acquired from the OECD Labour Force Statistics [79] and the Economic Freedom of the World (EFW) [80]. The two datasets were merged in order to complete the analysis.

The AGER survey has involved more than 50,000 participants since 2013. Data are collected in a face-to-face interview with a fully structured questionnaire utilizing CATI. However, due to limited access to the dataset, the present study involves the dataset from the 2017 survey in Austria, the United Kingdom, Italy, the United States and Brazil with 876, 694, 1328, 539, and 684 participants, respectively. All of the 4121 cases were selected from the country's population of men and women aged 15-64 years (the OECD's definition of the working age population) who are not self-employed individuals. The selection procedure ensured a representative sample for each country.

\subsection{Variables and Measures}

The proposed hypotheses are operationalized using the following variables, which are presented in Table 2. 
Table 2. Variables.

\begin{tabular}{|c|c|c|c|}
\hline & Coding & Level & \\
\hline \multicolumn{4}{|l|}{ Dependent variable } \\
\hline Intention & $\begin{array}{l}\text { Coded } 0 \text { for no intention, } 1 \text { for indifferent } \\
\text { intention, } 2 \text { for strong intention }\end{array}$ & Individual & AGER Survey \\
\hline \multicolumn{4}{|c|}{ Independent variables } \\
\hline $\begin{array}{l}\text { Unemployment } \\
\text { rate } 2016\end{array}$ & $\begin{array}{l}\text { Coded } 0 \text { for unemployment rate below } 5 \% \text { (low), } \\
1 \text { for } 5.01-10 \% \text { (medium), } 2 \text { for } 10.01-15 \% \text { (high) }\end{array}$ & National & $\begin{array}{l}\text { OECD Labour } \\
\text { Statistics }\end{array}$ \\
\hline EFW Index 2016 & $\begin{array}{l}\text { Coded } 0 \text { for "mostly free" and } 1 \text { for } \\
\text { "moderately free" }\end{array}$ & National & $\begin{array}{l}\text { Economic Freedom } \\
\text { of the World }\end{array}$ \\
\hline \multicolumn{4}{|l|}{ Control variables } \\
\hline Age & Scale (years) & Individual & AGER Survey \\
\hline Gender & Coded 0 for males and 1 for females & Individual & AGER Survey \\
\hline Education & $\begin{array}{l}\text { Coded } 1 \text { for lower secondary school, } 2 \text { for upper } \\
\text { secondary school and } 3 \text { for university graduate }\end{array}$ & Individual & AGER Survey \\
\hline $\begin{array}{l}\text { Willingness to } \\
\text { take risks }\end{array}$ & $\begin{array}{l}\text { Coded } 0 \text { for no and } 1 \text { for yes for the willingness } \\
\text { to take risks of failing }\end{array}$ & Individual & AGER Survey \\
\hline
\end{tabular}

\subsubsection{Dependent Variables}

Intention is measured based on the Amway Entrepreneurial Spirit Index (AESI). The AESI aims to capture three key motivational determinants that strengthen entrepreneurial potential, which is built on the theory of Planned Behaviour [18,81]. The three sub-dimensions are 1) desirability (the desire to create a start-up), 2) feasibility (the idea that the chances to create and manage a start-up are realistic) and 3) stability (the willingness to defend the implementation of a start-up even against a hostile environment of family and friends). Respondents were asked to agree with three statements relating to the above dimensions by indicating "yes" or "no". We coded "0" for no intention, i.e., for those respondents who did not consider starting a business, " 1 " for an indifferent intention, i.e., for those respondents who had considered starting a business yet either did not possess necessary skills and resources for starting a business or did not receive support from family/friends; and " 2 " for a strong intention, i.e., for those respondents who considered starting a business, possessed the skills and resources for starting a business and received support from family and friends to pursue that.

\subsubsection{Independent Variables}

To reflect societal and institutional contexts, this study relies on two variables: the EFW index and the rate of unemployment. The EFW index is "designed to measure the consistency of a nation's institutions and policies with economic freedom. In order to achieve a high EFW rating, a country must provide secure protection of privately owned property, even-handed enforcement of contracts, and a stable monetary environment. It must also keep taxes low, refrain from creating barriers to both domestic and international trade, and rely more fully on markets rather than political process to allocate goods and resources" ([82], p.7). This index is a measure of the extent to which institutions support the market. Based on the index, countries which score 80-100 are categorized as "free", a score of 70-79.9 is categorized as "mostly free", a score of 60-69.9 as "moderately free", a score of 50-59.9 as "mostly unfree" and a score 0-49.9 as "repressed" [80].

The unemployment rate is the number of unemployed people as a percentage of the labour force, where the latter consists of the unemployed plus those in wage- or salary-dependent employment or in self-employment. Unemployed people are those who report that they are without work, that they are available for work and that they have taken active steps to find work in the last four weeks. As the dependent variables were taken from a survey in 2017, the data for the employment rate are 
from the 2016 OECD Labour Statistics for Austria, the United Kingdom, Italy, the United States and Brazil. Although Brazil is not an OECD member, the data are available since Brazil is in the process of becoming a member.

\subsubsection{Control Variables}

We controlled for three demographic variables that have been found to be significant for entrepreneurial intention in the past. The first is age, measured in years. The second is gender, coded dichotomously as 0 for male and 1 for female. The third is education, categorized into lower secondary school, upper secondary school, and university graduate. The fourth variable is attitude towards risk, i.e., willingness to take risks of failing.

\section{Results}

\subsection{Description of Samples}

Table 3 shows the frequencies of the variables at an individual level data for all nationals. The sample is more or less equally divided between male and female at $47.2 \%$ and $52.8 \%$, respectively. The average age of respondents is 40 years, with the standard deviation of 14.2 years. By age group, respondents younger than 19 years are represented least in the sample. For the education level, $40.5 \%$ respondents completed lower secondary school, $35.7 \%$ upper secondary school and $23.8 \%$ graduated from university. With respect to their attitude towards risks, more than half of the respondents $(62.2 \%)$ expressed that they are not willing to take the risk of failing.

Table 3. Descriptive statistics.

\begin{tabular}{cccc}
\hline & \multicolumn{2}{c}{ Variables } & \multicolumn{2}{c}{ Frequencies } \\
\hline Intention & No Intention & 1799 & $43.7 \%$ \\
& Indifferent intention & 1205 & $29.2 \%$ \\
Gender & Strong intention & 1117 & $27.1 \%$ \\
& Male & 1946 & $47.2 \%$ \\
Education & Female & 2175 & $52.8 \%$ \\
& Lower secondary school & 1669 & $40.5 \%$ \\
\multirow{3}{*}{ Willingness to take risks } & Upper secondary school & 1473 & $35.7 \%$ \\
& University degree & 979 & $23.8 \%$ \\
& No & 2565 & $62.2 \%$ \\
& Yes & 1556 & $37.8 \%$ \\
\hline
\end{tabular}

Regarding unemployment, the rates vary considerably in an international comparison (see Table 4). According to the categorization in Table 2, the UK and the US have low unemployment rates while Austria and Brazil have moderate unemployment rates. Lastly, Italy has a high unemployment rate. For the Economic Freedom Index, the countries are divided into "mostly free" and "moderately free" according to the index. Austria, the UK and the US are countries which are "mostly free" while Italy and Brazil are "moderately free".

Table 4. Unemployment rate and EFW Index.

\begin{tabular}{ccccccc}
\hline Variables & Austria & UK & Italy & US & Brazil & Mean \\
\hline Unemployment rate 2016 & $6 \%$ & $4.8 \%$ & $11.7 \%$ & $4.9 \%$ & $9.6 \%$ & $7.96 \%$ \\
EFW Index 2016 & 71.7 & 76.4 & 61.2 & 75.4 & 56.5 & 67.57 \\
\hline
\end{tabular}

\subsection{Data Analysis}

A nonparametric statistical technique i.e., multinomial logistic regression is applied. Multinomial regression is taken to discuss the relationship between one nominal dependent variable and one or 
more independent variables. This technique offers a relaxed assumption of the linearity between the dependent and independent variables. Having more than two categories on a single dependent variable in the model, this technique is appropriate [83].

Firstly, to deal with multicollinearity, a test using SPSS (IBM Corporation, Armonk, NY, USA) requires the creation of dummy variables for the nominal variables. Afterward, the cut-off for VIF needs to be set, which is problematic [84,85]. This study uses a tolerance of 0.1 and a VIF of 10 , which is the critical threshold for multivariate analysis [84]. The VIF of all predictors falls between 1009 and 1896, indicating no multicollinearity. Further a check for a linear relationship between the dependent variable and the continuous independent variables was carried out. The study fulfilled the assumption criteria on this as well as on the assumption of no outliers in the data.

The model has a chi-square (16) 799.5; $p<0.001$. There is a decrease in unexplained variance from the baseline model (6735.4) to the final model (5936.8), which is a difference of 798.6. This change is significant, which means that the final model explains a significant amount of the original variability. Although we found no diversion in the model indicated by $\varnothing$ Pearson 1.064 and $\varnothing$ Deviance 1.15, our model only satisfies the Pearson indicator for the goodness of fit $\left(X^{2}=4206.08\right.$; $\mathrm{df} 3,9503950$, and $p>0.001$ ). All predictors have a significant main effect on the intention to self-employment with $p<0.001$ for age, risk, gender, education, and unemployment rate, and with $p=0.004$ for the EFW index. Overall, these likelihood statistics show that all predictors significantly enable us to predict the outcome category. The specific effect is shown by the individual parameter estimates in Table 5 .

Table 5. Multinomial logistic regression result for entrepreneurial intention.

\begin{tabular}{ccccccc}
\hline & \multicolumn{3}{c}{ Indifferent Intention } & \multicolumn{3}{c}{ Strong Intention } \\
\hline & \multicolumn{3}{c}{ Model 1 } & \multicolumn{3}{c}{ Model 2 } \\
\hline Variable & Coefficient & Std. Error & Odds Ratio & Coefficient & Std. Error & Odds Ratio \\
\hline Intercept & 1.431 & $0.193^{*}$ & & 1.565 & $0.202^{*}$ & \\
Age & -0.014 & $0.003^{*}$ & 0.986 & -0.019 & $0.003^{*}$ & 0.981 \\
Risk & -1.448 & $0.092^{*}$ & 0.235 & -1.847 & $0.095^{*}$ & 0.158 \\
Female & 0.297 & $0.082^{*}$ & 1.346 & 0.580 & $0.086^{*}$ & 1.786 \\
Education & -0.500 & $0.112^{*}$ & 0.607 & -0.601 & $0.118^{*}$ & 0.548 \\
EFW Index & -0.105 & 0.082 & 0.900 & 0.175 & $0.086^{* *}$ & 1.191 \\
Unemployment rate & -0.311 & $0.102^{* *}$ & 0.733 & -0.319 & $0.107^{* *}$ & 0.727 \\
\hline
\end{tabular}

Note: Reference category is no intention; ${ }^{*} p<0.001,{ }^{* *} p<0.05$.

The reference group consists of respondents having no intention to enter self-employment. Accordingly, each predictor has two parameters, one for predicting membership in the group of "indifferent intention" rather than the group of "no intention", and one for predicting membership in the group of "strong intention".

We firstly compare the group of "indifferent intention" with the group of "no intention". All the individual variables are significant when comparing the "indifferent intention" group with the "no intention" group. First, the variable of age predicts significantly whether someone has an indifferent intention to enter self-employment or no intention $\left(B=-0.014\right.$; Wald $\left.X^{2}(1)=23.859 ; p<0.001\right)$. For each one standard deviation increase in age, the odds of being in the group of "no intention" rather than in the group of "indifferent intention" are multiplicatively increased by 1.01. Second, regarding gender $\left(B=0.297\right.$; Wald $\left.X^{2}(1)=13.22 ; p<0.001\right)$, the odds ratio tells us that as gender changes from male (0) to female (1), the change in the odds of having indifferent intention (rather than no intention) is 1.346. This means the odds of respondents are more likely to have an indifferent intention than no intention if they are males. The third variable is about education $\left(B=-0.5\right.$; Wald $\left.X^{2}(1)=19.894 ; p<0.001\right)$ whose odds ratio is 0.607 . Respondents completing lower secondary school as compared to having a university degree are less likely to have a strong intention than no intention. Fourth, with regards to risk $\left(B=-1.448\right.$; Wald $\left.X^{2}(1)=246.973 ; p<0.001\right)$, the odds ratio tells us that respondents are more 
likely to have an indifferent intention rather than no intention if they have $1 / 0.235=4.26$ times more willingness to take risk.

Of the spatial and institutional variables, one predictor has an insignificant parameter for comparing the "no intention" group with the "indifferent intention" group, namely the EFW Index. The unemployment rate predicts significantly whether respondents have an indifferent intention to enter self-employment or no intention $\left(B=-0.311\right.$; Wald $\left.X^{2}(1)=9.331 ; p=0.002\right)$. The odds ratio shows that as the unemployment rate changes from medium $(5.01-10 \%)$ to high $(10.01-15 \%)$, the change in the odds is 0.733 . The odds of a high unemployment rate having an indifferent intention compared to no intention are $1 / 0.733=1.364$ more likely than for a medium unemployment rate.

Secondly, we compare the group with "strong intention" and those with "no intention". All variables show significant parameters. First, the odds ratio of age is 0.981 ( $B=-0.019$; Wald $\left.X^{2}(1)=40.611 ; p<0.001\right)$, which tells us that for an increase of one standard deviation, the odds of being in the group of "no intention" rather than the group of "strong intention" are increased by 1.02. Second, for gender $\left(B=0.580\right.$; Wald $\left.X^{2}(1)=45.2 ; p<0.001\right)$, the change in the odds of having a strong intention (rather than no intention) is 1.786. This means that the odds of respondents are more likely to have a strong intention than no intention if they are males. The third factor is about education ( $\mathrm{B}=-0.601$; Wald $\left.\mathrm{X}^{2}(1)=2.733 ; p<0.001\right)$, whose odds ratio is 0.548 , meaning that the odds of being in the group of "strong intention" rather than "no intention" are multiplicatively increased by 1.824. In other words, respondents completing lower secondary education compared to those with a university degree are less likely to have a strong intention than no intention. Fourth, with regards to risk $\left(\mathrm{B}=-1.847\right.$; Wald $\left.\mathrm{X}^{2}(1)=373.943 ; p<0.00\right)$, the odds ratio tells us that respondents are more likely to have a strong intention than no intention if they have $1 / 0.158=6.33$ times more willingness to take risk.

The two spatial and institutional variables, i.e., the EFW Index $\left(B=-0.175\right.$; Wald $X^{2}(1)=4.12$; $p<0.05)$ and unemployment rate $\left(B=-0.319\right.$; Wald $\left.X^{2}(1)=8.863 ; p<0.005\right)$ predict significantly whether respondents have a strong intention to enter self-employment or no intention. The odds ratio shows that as the EFW Index changes from "mostly free" (0) to "moderately free" (1), the change in the odds of having a strong intention (rather than no intention) is 1.191. This means that the odds of respondents are more likely to have a strong intention than no intention if they live in a country having an EFW index of "mostly free". Regarding the unemployment rate, the odds ratio shows that as the unemployment rate changes from medium (5.01-10\%) to high (10.01-15\%), the change in the odds is 0.727 . The odds of a high unemployment rate being a strong intention compared to no intention are $1 / 0.727=1-376$ more likely than for a medium unemployment rate. In other words, a medium unemployment rate compared to a high unemployment rate is less likely to have a strong intention than no intention.

\section{Discussion}

The present study shows that a higher unemployment rate is positively associated with the intention to be self-employed. This provides evidence for the argument that increasing unemployment rates push self-employment rates. Further the study also confirms that greater economic freedom is positively associated with the intention to self-employment by creating a new venture. Conversely, no association was revealed between economic freedom and an indifferent intention. However, hypothesis (I) is clearly confirmed by the positive link between the situation on the labour market and the degree to which people intend to self-employment. Too often this link is implicitly assumed: our data can give clear proof of this effect. Nevertheless, we do not observe a causal relationship but parallelism: the higher the unemployment rate is, the higher the reported degrees of intention to self-employment, not more, not less.

Differences between economies and societies are all about differences in social stratification, behavioural attitudes and the division of labour. Commonly we talk about varieties of capitalism [86], which are based on different histories and institutions internationally. Regulative systems, normative 
systems, and cultural-cognitive systems can be regarded as the three pillars of institutions [87]. Our research just referred to a limited set of independent variables, namely the unemployment rate and the economic freedom index, measuring the consistency of institutions supporting economic activities, combined with the control variables of age, gender, education, and risk attitude.

With regards to age, there have been limited studies on intention showing conclusive finding since most studies relied on sample of university students within the age of 18-30 years. This study finds interesting result that people at younger age tend to have strong intention to self-employment. This study also reveals that man have stronger intention to self-employment than woman, confirming the result of past studies [20,36]. Despite the allure of entering self-employment for woman, the consistent difference in women and men's entrepreneurial activity makes it important to understand why women have less intention entering self-employment than men. This certainly beyond the scope of this article.

Regarding level of education, this study finds that people with higher level of education tend to have strong intention to self-employment. The level of education might affect the propensity to enter self-employment through several factors. Education enhance skills and knowledge especially managerial skills [70] which is essential to be a self-employed. Education generates higher level of perceived entrepreneurial ability which drives stronger intention to self-employment [18]. Lastly, our study confirms that higher wiliness to take risks affect the level of intention entering self-employment.

North [88]'s analysis of institutions was primarily to learn to understand "the underlying rules of the game and the focus on organizations (and their entrepreneurs) ... primarily on their role as agents of institutional change" (p. 5). In his reflections on economic change, North [88] clearly saw the link between entrepreneurial choices and different levels of intentions: "The choices made reflect the entrepreneurs' subjective modelling of the environment. Therefore, the degree to which outcomes are consistent with intentions will reflect the degree to which the entrepreneur's models are true models" (p. 104).

When the topic of the paper is understood in this theoretical framework, intentions will become a pivot of economic discussion. Cross-national differences in institutions and intentions may help to explain different degrees of institutional change in relation to different forms of economic motivation, insofar as intentions really seem to be a crucial variable. A sample of different countries like Austria, the UK, Italy, the US and Brazil may show significant differences in the institutional rules of the game. However, factors which work as independent variables in all countries in the same direction also become very visible, especially the unemployment rate. In a nutshell, the better labour market conditions seemingly are, the lower the intentions to self-employment, and vice versa, the worse the labour market data prove to be and the higher the corresponding unemployment figures are rising, the stronger the intentions to self-employment. Very much of the ongoing discussion on intentions to self-employment completely ignores the fact that self-employment is very heterogeneous and includes different career patterns and diverse social and economic conditions [89]. The findings presented here also provide significant proof of the fact that society matters. The interplay of different societal variables shows that divergent items contribute to an adequate understanding of an economic mechanism which has its roots in multiple academic responsibilities and which needs integrating into entrepreneurship research of an interdisciplinary nature [90]. Insofar as the finding that society matters is confirmed properly, the paper is not only a contribution to institutional entrepreneurship research but also to the discussion taking place under the umbrella of contextual entrepreneurship research [91].

\section{Conclusions}

As already argued by Knight [92], self-employment returns are intrinsically riskier than returns from wage employment. Therefore risk-averse individuals demand greater expected returns in order to enter self-employment [93]. Our findings confirm this. Even here, the different contextual variables of women's entrepreneurship interrelate with different propensities, cognitions, and chances in the welfare system, which reflect a specific framework [53]. Risk perception is never an absolute perception 
but always relative compared to the alternatives, which determine material but also social prices. In addition, comparing countries like Austria, Brazil, Italy, the UK, and the US hints at completely different meso and macro environments which may give reason to see the divergences rather than the convergences [94]. To increase the quality of cross-national observations, more countries need to be included. The survey in this article seems to be a reasonable starting point but the quality and depth of the discussion will be strengthened if further country data can be involved.

Our research has several limitations which may provide avenues for further research. First, our sample consists of a limited number of countries which were selected based on the availability of data. It is important to include more countries to reveal whether the findings will hold true. Second, our dataset involves a cross-section data which is the year of 2017. Though this data is very recent, panel dataset will offer better understanding of the phenomenon through the years. Third, the study only measured intention to enter entrepreneurship in general (strong, indifferent, and no intention); further studies may investigate the nature of that intention, i.e., opportunity versus necessity. Lastly, with regard to economic freedom, the present study only utilized the index, which hinders investigations of the sub-components of economic freedom. More detailed investigations of such sub-components will provide detailed explanations of the institutions associated with entrepreneurship and thus more guidance can be offered to policy makers.

Turning to the microfoundations of embedded agency [95] helps to understand the hidden logics of economic behaviour, where actors have their own script to do what they are doing (or not doing). These subtle forms of rationality become very visible when investigating processes of the social construction of local communities [96]. Lower ratios for the intentions of women may for example reflect a form of discrimination in society but can indicate even more realistic perceptions by women. Especially, international comparisons allow us to explore the institutional constraints of intentions and the behaviour of female entrepreneurs [94].

Author Contributions: Conceptualization: Z.P. and D.B.; methodology: Z.P.; software: Z.P.; formal analysis: Z.P.; investigation: Z.P. and D.B.; resources: D.B.; data curation: Z.P.; writing-original draft preparation: Z.P. and D.B.; writing-review and editing: Z.P. and D.B.; visualization: Z.P.; supervision: D.B.; project administration: Z.P. and D.B.

Funding: This research received no external funding

Acknowledgments: Earlier versions of this paper were presented at the CRSE Global Workshop on Freelancing and Self-Employment, London, April 26-27, 2018, and the 5th International Scientific Conference: Entrepreneurship for the 21st Century. Images and Perspectives, University of Warsaw, November 15-16, 2018. Authors are grateful for comments provided by three reviewers and editor which helped to strengthen the argumentation. Special thanks goes the Amway Global Entrepreneurship Research (AGER) consortium which provided access to the data.

Conflicts of Interest: The authors declare no conflict of interest.

\section{References}

1. Audretsch, D.B.; Thurik, R.; Verheul, I.; Wennekers, S. Entrepreneurship: Determinants and Policy in a European-US Comparison; Springer Science \& Business Media: Berlin, Germany, 2002; Volume 27.

2. Liñán, F.; Rodríguez-Cohard, J.C.; Rueda-Cantuche, J.M. Factors affecting entrepreneurial intention levels: A role for education. Int. Entrep. Manag. J. 2011, 7, 195-218. [CrossRef]

3. Mitra, J. Towards an analytical framework for policy development. Entrep. High. Educ. 2008, 17-44.

4. Fayolle, A.; Liñán, F. The future of research on entrepreneurial intentions. J. Bus. Res. 2014, 67, 663-666. [CrossRef]

5. Brännback, M.; Carsrud, A.L. Where do we go from here? A research agenda for entrepreneurial cognitions. In A Research Agenda for Entrepreneurial Cognition and Intention; Brännback, M., Carsrud, A.L., Eds.; Edward Elgar: Cheltenham, UK, 2018.

6. Liñán, F.; Fayolle, A. A systematic literature review on entrepreneurial intentions: Citation, thematic analyses, and research agenda. Int. Entrep. Manag. J. 2015, 11, 907-933. [CrossRef]

7. Shane, S.; Venkataraman, S. The promise of entrepreneurship as a field of research. Acad. Manag. Rev. 2000, 25, 217-226. [CrossRef] 
8. Bernoster, I.; Rietveld, C.; Thurik, A.; Torrès, O. Overconfidence, Optimism and Entrepreneurship. Sustainability 2018, 10, 2233. [CrossRef]

9. Proeger, T.; Meub, L. Overconfidence as a social bias: Experimental evidence. Econ. Lett. 2014, 122, $203-207$. [CrossRef]

10. Moore, D.A.; Healy, P.J. The trouble with overconfidence. Psychol. Rev. 2008, 115, 502-517. [CrossRef]

11. Astebro, T.; Herz, H.; Nanda, R.; Weber, R.A. Seeking the Roots of Entrepreneurship: Insights from Behavioural Economics. J. Econ. Perspect. 2014, 28, 49-70. [CrossRef]

12. Hofstede, G. Culture's Consequences: Comparing Values, Behaviours, Institutions and Organizations across Nations; Sage Publications: Thousand Oaks, CA, USA, 2001.

13. Block, J.; Landgraf, A.; Semrau, T. The differential impact of societal cultural practices on part-time and full-time self-employment: A multi-level, multi-country study. Int. Small Bus. J. 2018, 37. [CrossRef]

14. Bandura, A. Social cognitive theory: An agentic perspective. Annu. Rev. Psychol. 2001, 52, 1-26. [CrossRef] [PubMed]

15. Krueger, N.F.; Reilly, M.D.; Carsrud, A.L. Competing models of entrepreneurial intentions. J. Bus. Ventur. 2000, 15, 411-432. [CrossRef]

16. Bird, B. Implementing Entrepreneurial Ideas: The Case for Intention. Acad. Manag. Rev. 1988, 13, 442-453. [CrossRef]

17. Shapero, A.; Sokol, L. The social dimensions of entrepreneurship. In Encyclopedia of Entrepreneurship; Kent, C.A., Sexton, D.L., Vesper, K.H., Eds.; Prentice-Hall: Upper Saddle River, NJ, USA, 1982; pp. 72-90.

18. Ajzen, I. The theory of planned behaviour. Organ. Behav. Hum. Decis. Process. 1991, 50, 179-211. [CrossRef]

19. Engle, R.L.; Dimitriadi, N.; Gavidia, J.V.; Schlaegel, C.; Delanoe, S.; Alvarado, I.; He, X.; Buame, S.; Wolff, B. Entrepreneurial intent: A twelve-country evaluation of Ajzen's model of planned behaviour. Int. J. Entrep. Behav. Res. 2010, 16, 35-57. [CrossRef]

20. Iakovleva, T.; Kolvereid, L.; Stephan, U. Entrepreneurial intentions in developing and developed countries. Educ. + Train. 2011, 53, 353-370.

21. Van Gelderen, M.; Brand, M.; van Praag, M.; Bodewes, W.; Poutsma, E.; van Gils, A. Explaining entrepreneurial intentions by means of the theory of planned behaviour. Career Dev. Int. 2008, 13, 538-559. [CrossRef]

22. Liñán, F.; Chen, Y.W. Development and Cross-Cultural Application of a Specific Instrument to Measure Entrepreneurial Intentions. Entrep. Theory Pract. 2009, 33, 593-617. [CrossRef]

23. Bandura, A. Self-efficacy: Toward a unifying theory of behavioural change. Psychol. Rev. 1977, 84, 191. [CrossRef]

24. Ajzen, I. Perceived Behavioural Control, Self-Efficacy, Locus of Control, and the Theory of Planned Behaviour. J. Appl. Soc. Psychol. 2002, 32, 665-683. [CrossRef]

25. Welter, F. Contextualizing Entrepreneurship-Conceptual Challenges and Ways Forward. Entrep. Theory Pract. 2011, 35, 165-184. [CrossRef]

26. Zahra, S.A.; Wright, M.; Abdelgawad, S.G. Contextualization and the advancement of entrepreneurship research. Int. Small Bus. J. 2014, 32, 479-500. [CrossRef]

27. Moriano, J.A.; Gorgievski, M.; Laguna, M.; Stephan, U.; Zarafshani, K. A Cross-Cultural Approach to Understanding Entrepreneurial Intention. J. Career Dev. 2012, 39, 162-185. [CrossRef]

28. Walker, J.K.; Jeger, M.; Kopecki, D. The Role of Perceived Abilities, Subjective Norm and Intentions in Entrepreneurial Activity. J. Entrep. 2013, 22, 181-202. [CrossRef]

29. Hessels, J.; Grilo, I.; Thurik, R.; van der Zwan, P. Entrepreneurial exit and entrepreneurial engagement. J. Evol. Econ. 2011, 21, 447-471. [CrossRef]

30. North, D.C. Institutions. J. Econ. Perspect. 1991, 5, 97-112. [CrossRef]

31. Voigt, S. How to measure informal institutions. J. Inst. Econ. 2018, 14, 1-22. [CrossRef]

32. Voigt, S. How (not) to measure institutions. J. Inst. Econ. 2013, 9, 1-26. [CrossRef]

33. Jackson, G.; Deeg, R. Comparing capitalisms: Understanding institutional diversity and its implications for international business. J. Int. Bus. Stud. 2008, 39, 540-561. [CrossRef]

34. Liñán, F.; Urbano, D.; Guerrero, M. Regional variations in entrepreneurial cognitions: Start-up intentions of university students in Spain. Entrep. Reg. Dev. 2011, 23, 187-215. [CrossRef]

35. Capelleras, J.-L.; Mole, K.F.; Greene, F.J.; Storey, D.J. Do More Heavily Regulated Economies Have Poorer Performing New Ventures? Evidence from Britain and Spain. J. Int. Bus. Stud. 2008, 39, 688-704. [CrossRef] 
36. Engle, R.L.; Schlaegel, C.; Dimitriadi, N. Institutions and Entrepreneurial Intent: A cross-country study. J. Dev. Entrep. 2011, 16, 227-250. [CrossRef]

37. Jaén, I.; Liñán, F. Cultural values in the study of a society's entrepreneurial potential. In Developing, Shaping and Growing Entrepreneurship; Fayolle, A., Kyrö, P., Liñán, F., Eds.; Edward Elgar: Cheltenham, UK, 2015; pp. 154-177.

38. Davidsson, P.; Wiklund, J. Values, beliefs and regional variations in new firm formation rates. J. Econ. Psychol. 1997, 18, 179-199. [CrossRef]

39. Hayton, J.C.; George, G.; Zahra, S.A. National culture and entrepreneurship: A review of behavioural research. Entrep. Theory Pract. 2002, 26, 33-52. [CrossRef]

40. McMullen, J.S.; Bagby, D.R.; Palich, L.E. Economic freedom and the motivation to engage in entrepreneurial action. Entrep. Theory Pract. 2008, 32, 875-895. [CrossRef]

41. Angulo-Guerrero, M.J.; Pérez-Moreno, S.; Abad-Guerrero, I.M. How economic freedom affects opportunity and necessity entrepreneurship in the OECD countries. J. Bus. Res. 2017, 73, 30-37. [CrossRef]

42. Powell, B.; Weber, R. Economic freedom and entrepreneurship: A panel study of the United States. Am. J. Entrep. 2013, 6, 67.

43. Blanchflower, D.G. Self-employment in OECD countries. Labour Econ. 2000, 7, 471-505. [CrossRef]

44. Constant, A.F.; Zimmermann, K.F. Self-employment against employment or unemployment: Markov transitions across the business cycle. Eurasian Bus. Rev. 2014, 4, 51-87. [CrossRef]

45. Evans, D.S.; Leighton, L.S. Small business formation by unemployed and employed workers. Small Bus. Econ. 1990, 2, 319-330. [CrossRef]

46. Thurik, A.R.; Carree, M.A.; van Stel, A.; Audretsch, D.B. Does self-employment reduce unemployment? J. Bus. Ventur. 2008, 23, 673-686. [CrossRef]

47. Falco, P.; Haywood, L. Entrepreneurship versus joblessness: Explaining the rise in self-employment. J. Dev. Econ. 2016, 118, 245-265. [CrossRef]

48. Dvouletý, O. Does the Self-employment Policy Reduce Unemployment and Increase Employment? Empirical Evidence from the Czech Regions. Cent. Eur. J. Public Policy 2017, 11, 11-22. [CrossRef]

49. Moore, C.S.; Mueller, R.E. The transition from paid to self-employment in Canada: The importance of push factors. Appl. Econ. 2002, 34, 791-801. [CrossRef]

50. Shinnar, R.S.; Giacomin, O.; Janssen, F. Entrepreneurial Perceptions and Intentions: The Role of Gender and Culture. Entrep. Theory Pract. 2012, 36, 465-493. [CrossRef]

51. Strobl, A.; Kronenberg, C.; Peters, M. Entrepreneurial attitudes and intentions: Assessing gender specific differences. Int. J. Entrep. Small Bus. 2012, 15, 452-468. [CrossRef]

52. Haus, I.; Steinmetz, H.; Isidor, R.; Kabst, R. Gender effects on entrepreneurial intention: A meta-analytical structural equation model. Int. J. Gend. Entrep. 2013, 5, 130-156. [CrossRef]

53. Brush, C.G.; De Bruin, A.; Welter, F. A gender-aware framework for women's entrepreneurship. Int. J. Gend. Entrep. 2009, 1, 8-24. [CrossRef]

54. Kirkwood, J.; Tootell, B. Is entrepreneurship the answer to achieving work-family balance? J. Manag. Organ. 2008, 14, 285-302.

55. Wellington, A.J. Self-employment: The new solution for balancing family and career? Labour Econ. 2006, 13, 357-386. [CrossRef]

56. Noseleit, F. Female self-employment and children. Small Bus. Econ. 2014, 43, 549-569. [CrossRef]

57. Minniti, M. Female entrepreneurship and economic activity. Eur. J. Dev. Res. 2010, 22, 294-312. [CrossRef]

58. Nelson, T.; Ahl, H. Moving forward: Institutional perspectives on gender and entrepreneurship. Int. J. Gend. Entrep. 2010, 2, 5-9.

59. Duberley, J.; Carrigan, M. The career identities of 'mumpreneurs': Women's experiences of combining enterprise and motherhood. Int. Small Bus. J. 2013, 31, 629-651. [CrossRef]

60. Calderon, G.; Iacovone, L.; Juarez, L. Opportunity versus Necessity: Understanding the heterogeneity of female micro-entrepreneurs. World Bank Econ. Rev. 2017, 30, 86-96.

61. Dvouletý, O.; Lukeš, M. Review of empirical studies on self-employment out of unemployment: Do selfemployment policies make a positive impact? Int. Rev. Entrep. 2016, 14, 361-376.

62. Dvouletý, O. How to analyse determinants of entrepreneurship and self-employment at the country level? A methodological contribution. J. Bus. Ventur. Insights 2018, 9, 92-99. [CrossRef] 
63. Maes, J.; Leroy, H.; Sels, L. Gender differences in entrepreneurial intentions: A TPB multi-group analysis at factor and indicator level. Eur. Manag. J. 2014, 32, 784-794. [CrossRef]

64. Backman, M.; Karlsson, C. Who Says Life Is over after 55? Entrepreneurship and an Aging Population; Centre of Excellence for Science and Innovation Studies, The Royal Institute of Technology: Jönköping, Sweden, 2013.

65. Kautonen, T. Understanding the older entrepreneur: Comparing third age and prime age entrepreneurs in Finland. Int. J. Bus. Sci. Appl. Manag. 2008, 3, 3-13.

66. Mayer, K.U. New directions in life course research. Annu. Rev. Sociol. 2009, 35, 413-433. [CrossRef]

67. Coleman, S.; Cotei, C.; Farhat, J. A Resource-based view of new firm survival: New perspectives on the role of industry and exit route. J. Dev. Entrep. 2013, 18, 1. [CrossRef]

68. Hsu, D.H. Experienced entrepreneurial founders, organizational capital, and venture capital funding. Res. Policy 2007, 36, 722-741. [CrossRef]

69. Mas-Tur, A.; Pinazo, P.; Tur-Porcar, A.M.; Sánchez-Masferrer, M. What to avoid to succeed as an entrepreneur. J. Bus. Res. 2015, 68, 2279-2284. [CrossRef]

70. Van der Sluis, J.; van Praag, M.; Vijverberg, W. Entrepreneurship Selection and Performance: A Meta-Analysis of the Impact of Education in Developing Economies. World Bank Econ. Rev. 2005, 19, 225-261. [CrossRef]

71. Dickson, P.H.; Solomon, G.T.; Weaver, K.M. Entrepreneurial selection and success: Does education matter? J. Small Bus. Enterp. Dev. 2008, 15, 239-258. [CrossRef]

72. Bae, T.J.; Qian, S.; Miao, C.; Fiet, J.O. The Relationship Between Entrepreneurship Education and Entrepreneurial Intentions: A Meta-Analytic Review. Entrep. Theory Pract. 2014, 38, 217-254. [CrossRef]

73. Parker, S.C. The Effects of Risk on Self-Employment. Small Bus. Econ. 1997, 9, 515-522. [CrossRef]

74. Kihlstrom, R.E.; Laffont, J.-J. A general equilibrium entrepreneurial theory of firm formation based on risk aversion. J. Political Econ. 1979, 87, 719-748. [CrossRef]

75. Jovanovic, B. Selection and the Evolution of Industry. Econometrica 1982, 50, 649-670. [CrossRef]

76. Shepherd, D.A.; Williams, T.A.; Patzelt, H. Thinking About Entrepreneurial Decision Making: Review and Research Agenda. J. Manag. 2015, 41, 11-46. [CrossRef]

77. Dew, N.; Read, S.; Sarasvathy, S.D.; Wiltbank, R. Effectual versus predictive logics in entrepreneurial decision-making: Differences between experts and novices. J. Bus. Ventur. 2009, 24, 287-309. [CrossRef]

78. GFK-Institute. AGER 2018 Amway Global Entrepreneurship Report; GFK Institute: Nuremberg, Germany, 2018.

79. OECD. OECD Labour Force Statistics 2017; OECD: Paris, France, 2018.

80. Miller, T.; Kim, A.B. 2016 Index of Economic Freedom; The Heritage Foundation and Dow Jones \& Company, Inc.: Washington, DC, USA, 2016.

81. Krueger, N.F., Jr.; Brazeal, D.V. Entrepreneurial Potential and Potential Entrepreneurs. Entrep. Theory Pract. 1994, 18, 91-104. [CrossRef]

82. Gwartney, J.; Lawson, R.; Sobel, R.S.; Leeson, P.T. Economic Freedom of the World; Fraser Institute: Vancouver, BC, Canada, 2007.

83. Fox, J. Multiple and Generalized Nonparamteric Regression; Sage Publications: Thousand Oaks, CA, USA, 2000.

84. Hair, J.F.; Black, W.C.; Babin, B.J.; Anderson, R.E. Multivariate Data Analysis; Prentice Hall: Upper Saddle River, NJ, 2009.

85. Kock, N.; Lynn, G.S. Lateral Collinearity and Misleading Results in Variance-Based SEM: An Illustration and Recommendations. J. Assoc. Inf. Syst. 2012, 13, 2. [CrossRef]

86. Hall, P.A. Varieties of capitalism. In Emerging Trends in the Social and Behavioural Sciences: An Interdisciplinary, Searchable, and Linkable Resource; John Wiley \& Sons, Inc.: Hoboken, NJ, USA, 2015; pp. 1-15.

87. Scott, W.R. Institutions and Organizations: Ideas, Interests, and Identities; SAGE Publications: Thousand Oaks, CA, USA, 2013.

88. North, D.C. Institutions, Institutional Change and Economic Performance; Cambridge University Press: Cambridge, MA, USA, 1991.

89. Bögenhold, D. From Hybrid Entrepreneurs to Entrepreneurial Billionaires: Observations on the Socioeconomic Heterogeneity of Self-employment. Am. Behav. Sci. 2018, 62. [CrossRef]

90. Bögenhold, D.; Fink, M.; Kraus, S. Integrative entrepreneurship research-Bridging the gap between sociological and economic perspectives. Int. J. Entrep. Ventur. 2014, 6, 118-139. [CrossRef]

91. Welter, F.; Gartner, W.B.; Wright, M. The context of contextualizing contexts. In A Research Agenda for Entrepreneurship and Context; Welter, F., Gartner, W.B., Eds.; Edward Elgar: Cheltenham, UK, 2016; pp. 1-15.

92. Knight, F.H. Risk, Uncertainty and Profit; Houghton Mifflin: New York, NY, USA, 1921. 
93. Reschke, C.H.; Bögenhold, D.; Kraus, S. How innovation and entrepreneurship can conquer uncertainty and complexity: Learning about the unexpected. Int. J. Complex. Leadersh. Manag. 2010, 1, 55-71. [CrossRef]

94. Klyver, K.; Nielsen, S.L.; Evald, M.R. Women's self-employment: An act of institutional (dis)integration? A multilevel, cross-country study. J. Bus. Ventur. 2013, 28, 474-488. [CrossRef]

95. Thornton, P.H.; Ocasio, W. Institutional logics. In Handbook of Organizational Institutionalism; Greenwood, R., Oliver, C., Suddaby, R., Salin, K., Eds.; Sage: Thousand Oaks, CA, USA, 2008; pp. 99-129.

96. Jack, S.L.; Anderson, A.R. The effects of embeddedness on the entrepreneurial process. J. Bus. Ventur. 2002, 17, 467-487. [CrossRef]

(C) 2019 by the authors. Licensee MDPI, Basel, Switzerland. This article is an open access article distributed under the terms and conditions of the Creative Commons Attribution (CC BY) license (http://creativecommons.org/licenses/by/4.0/). 